Cultural Journalism and Cultural Critique in a Changing Media Landscape

Kristensen, Nete Nørgaard; From, Unni

Published in:

Journalism Practice

DOI:

10.1080/17512786.2015.1051357

Publication date:

2015

Document version

Peer reviewed version

Citation for published version (APA):

Kristensen, N. N., \& From, U. (2015). Cultural Journalism and Cultural Critique in a Changing Media Landscape. Journalism Practice, 9(6), 760-772. https://doi.org/10.1080/17512786.2015.1051357 


\title{
Cultural Journalism and Cultural Critique in a changing Media Landscape
}

Nete Nørgaard Kristensen, University of Copenhagen, Denmark, netenk@hum.ku.dk

Unni From, Aarhus University, Denmark

Published in Journalism Practice 2015, online first. DOI: 10.1080/17512786.2015.1051357

(C) The Author(s) 2015, available at: http://dx.doi.org/10.1080/17512786.2015.1051357

\begin{abstract}
This special issue addresses a topic of journalism studies that has previously been somewhat neglected but which has gained increasing scholarly attention since the mid-2000s: the coverage and evaluation of art and culture, or what we term "cultural journalism and cultural critique." In this introduction, we highlight three issues that serve to frame the study of cultural journalism and cultural critique more generally and the eight articles of this special issue more specifically: (1) the constant challenge of demarcating cultural journalism and cultural critique, including the interrelations of "journalism" and "critique"; (2) the dialectic of globalisation's cultural homo- genisation, on the one hand, and the specificity of local/national cultures, on the other; and (3) the digital media landscape seen in terms of the need to rethink, perhaps even redefine cultural journalism and cultural critique.
\end{abstract}

KEYWORDS cultural critics; cultural critique; cultural journalism; digital journalism; digital media; news production

\section{Introduction: Cultural Journalism and Cultural Critique as Emerging Research Areas}

Politics, art, and culture have since the introduction of newspapers in Western societies been covered sideby-side by various and more or less critical writers, of which journalists were just one variety. However, journalism research has a long tradition of prioritising political journalism and news media, primarily as a political public sphere. Likewise, political journalism increasingly came to set the agenda in the newsrooms and in journalism education during the twentieth century. This political leaning in both research and practice is closely linked to the professional and normative ideal or ideology of Western journalism, an ideal that stipulates an autonomous, objective, and versatile press, performing the role of society's watchdog and addressing urgent events and issues of societal importance as a constituent element of democracy (e.g., Curran 2011; Deuze 2005). Thus in many ways the political bias is fully justified.

One consequence, however, has been the neglect by scholars of the news media's coverage of "softer" issues such as art, culture, lifestyle, "life politics" (Giddens 1992), and the cultural public spherewhat we, in this special issue, term "cultural journalism." In much the same way, journalists covering these issues have consistently had to defend their work to their peers and the public (see Harries and WahlJorgensen 2007; Hovden and Knapskog 2015). This scholarly inattention as well as the professional need for justification are striking in light of the fact that these topics have become increasingly important parts of news production during the twentieth century and are today covered intensively (e.g., Janssen, Kuipers, and Verboord 2008; Kristensen and From 2011). When occasionally addressed by scholars, these topics have typically been analysed in relation to political journalism. Political journalism has been viewed as the proper kind of journalism, "the real journalism" (Deuze 2005, 444), while the expansion of topics such as culture, lifestyle, and consumption has been viewed as part of the tabloidisation and commercia- lisation of journalism (e.g., Hanusch 2012; Reinemann et al. 2011). In continuation of these claims, cultural journalists have repeatedly been criticised for unhealthy interdependencies with the cultural industries or with the market (Bech-Karlsen 1991; Lund 2005; Marshall 2006; Strahan 2011), challenging core roles and values of journalism in democracy. Simply, these topics have been viewed as less legitimate kinds of journalism in their own right and analysed on their own terms - which also explains the need for cultural journalists constantly to defend their professional practice. 
However, new research on arts and cultural journalism, cultural critique, and the cultural public sphere is currently emerging (e.g., Hanusch 2012; Hellman and Jaakkola 2012; Jaakkola 2014; Janssen, Kuipers, and Verboord 2008; Janssen, Verboord, and Kuipers 2011; Knapskog and Larsen 2008; Kristensen 2010; Kristensen and From 2011, 2012, 2015b). Cultural journalism is therefore a growing subfield of considerable public significance. In this introduction, we highlight three important and interrelated issues in existing cultural journalism research as frameworks for the eight contributions in this special issue: (1) the constant challenge of demarcating cultural journalism and cultural critique, including the interrelations of "journalism" and "critique"; (2) the dialectic—at the centre of much national and comparative cultural journalism research — of globalisation's cultural standardisation, on the one hand, and the specificity of local/national cultures, on the other; and (3) the digital media landscape seen in terms of the need to rethink, perhaps even redefine cultural journalism and cultural critique.

Taken together, these issues point towards contemporary journalism being in a state of flux. The boundaries of hard news and soft news are blurring (Reinemann et al. 2011), as are the generic conventions of news and views (Hjarvard 2010; Jacobs and Townsley 2011) as well as the conceptions of professionals and non-professionals (Bruns 2008; Jenkins 2006). Cultural journalism finds itself in the midst of these disruptions and may therefore serve as a prism for studying and understanding the challenges and opportunities currently facing journalism.

\section{Demarcating Cultural Journalism and Cultural Critique as Analytical Objects}

Why a special issue on cultural journalism and cultural critique? Some scholars (Bech-Karlsen 1991; Lund 2005) and recurring critical voices in the public debate (e.g., Marker 2014) argue that we have witnessed a decline in the quality of cultural journalism. They interpret the increasing personalisation and sensationalisation (Gripsrud 2000) of the coverage of art and culture as a transformation from critical cultural reflection to publicity- driven journalism, entertainment, and celebrity gossip, i.e. as a debasement of arts and cultural journalism. Expressed differently, they criticise a development in cultural journalism from "cultural critique" to "cultural service journalism." In this special issue, we approach the association of cultural journalism and cultural critique not as oppositional, incompatible concepts but as mutually dependent parts of a complex equation: while cultural journalism is in some contexts more likely to take shape as intellectual and reflective criticism of culture and society, e.g. when cartoons in the cultural section put ideologies and freedom rights to the test, cultural critique or critical-analytical journalistic discourses, for example in specialised magazines, may provide legitimacy for the cultural journalistic exploration of popular consumerist culture such as television series (Baumann 2001, 2007; Béliard 2015). In fact, historically there have been close connections between cultural journalism and cultural critique: cultural critique has been scrutinised by scholars for many years from within a variety of disciplines with an emphasis on the news media, or cultural journalism, as one of several important institutional frameworks for the practice of cultural critique (e.g., Bordwell 1991; Said 1984). This is, not least, because the review has been a constitutive genre of cultural journalism. Accordingly, recent research has focused on new types of cultural critique or reviewing facilitated by digital media technologies. These potentially circumvent the traditional division of labour between critics, professional cultural journalists, and amateurs (e.g., Holopirek 2007; Verboord 2014), and may offer new opportunities and challenges for the conceptualisation of "critique." We shall return to this question below, as it is addressed in several articles in this special issue.

What constitutes the "cultural" in cultural journalism and cultural critique is a complex question. As a consequence, scholars use various terms for sometimes the same, sometimes quite different things-arts journalism, cultural journalism, soft news, literary critiques, art reviews, etc. This lack of precision or clear demarcation may be explained by the fact that cultural journalism is associated with larger societal and media cultural phenomena and trends, such as the arts, lifestyles, tastes, literacy, cultural competencies, value politics, etc. A broadly encompassing term for this is "the cultural field" (Bourdieu 1993; Knapskog and Larsen 2008, 11). During the past decades this field has expanded considerably, and one result is that the research potential for cultural journalism scholars has become extremely wide-ranging. Therefore, existing cultural journalism research appears somewhat fragmented and, in some cases, empirically quite 
narrowly delineated, since, typically in the form of book chapters and research articles, it tends to address specific sub-areas of the broad cultural field. This is the case, to name just a few, with Turner and Orange's (2013) edited volume on specialist journalism, which, among other things, includes chapters on food journalism, fashion journalism, music journalism, travel journalism, and wine journalism; or Hanusch's special issue of Journalism Practice and his later edited collection on lifestyle journalism (2013), which includes articles on travel journalism, food journalism, health journalism, and fashion journalism; or Dubied and Hanitzsch's (2014) special issue of Journalism: Theory, Practice and Criticism on celebrity news. These specialised types of journalism could all be covered by the term "cultural journalism" in a broad sense. More recently, such analyses of the journalistic approach to and coverage of specific sub-areas within the wide concept of "culture" have been supplemented by studies pointing to the close links between the "political" and the "cultural" in cultural journalism (Knapskog and Larsen 2008; McGuigan 2005), in the sense that cultural journalism also addresses political issues through the artistic and popular cultural expressions it debates and contextualises. In some contexts, one might even argue for a repoliticisation of cultural journalism, since important political issues of contempor- ary society originate from debates on the cultural pages on topics such as religion, race, and immigration (Riegert, Roosvall, and Widholm 2015). The Cartoon Controversy (2006) (e.g., Berkowitz and Eko 2007) and the Charlie Hebdo attack (2015) are two global (and extreme) examples.

In this special issue, as indicated, we use "cultural journalism" as an umbrella term for the media's reporting and debating on culture, including the arts, value politics, popular culture, the culture industries, and entertainment. Some of the articles included conse- quently apply a broad approach to "the cultural" when theorising and analysing the self- perception of cultural editors, the professional ideology and legitimacy struggles of cultural journalists, or the production and content of cultural journalism. Other contributions demarcate their field of study more narrowly, both topically and generically, by engaging with very specific sub-areas such as "film criticism" or "television series."

\section{Homogenisation and Diversity in the Coverage of Culture}

Another way of approaching cultural journalism is from a geographical perspective, since national media models and cultural policy traditions constitute particular premises and roles for cultural journalism (e.g., Gripsrud 2009; Janssen, Kuipers, and Verboord 2008). In a Western context, it has been argued that a liberal media model has become increasingly dominant (Hallin and Mancini 2004) and consequently an increased homogenisation and commercialisation of journalism in general and cultural journalism in particular. Similarly, cultural globalisation has transformed the cultural public sphere during the twentieth century. It is held responsible for cultural homogenisation by some critics (e.g., Herman and McChesney 1997), while others argue that cultural diversity has increased (e.g., Appadurai 1996). In the case of cultural journalism, one outcome of these changes is that its cultural focus has expanded considerably, as also indicated above (e.g., Janssen 1999; Knapskog and Larsen 2008; Kristensen and From 2011), resulting in an increasingly diverse cultural palette being covered. However, we also see signs of cultural homogenisation in arts coverage (Janssen, Kuipers, and Verboord 2008), and we see cultural journalismitself part of the globalised cultural structures (Kristensen 2010)_both mirroring and amplifying these socio- cultural changes.

However, the few, existing comparative studies of cultural journalism (Janssen, Kuipers, and Verboord 2008; Janssen, Verboord, and Kuipers 2011) also show that arts and cultural journalism are still closely connected to and occupied with national identity and national cultural institutions. This implies that there are national variations between media systems when it comes to the prioritising, conceptualisation, and outlook over the cultural in cultural journalism (see also Kristensen 2015). These variations are confirmed by single- country studies of cultural journalism, which have become more numerous especially since the early 2000s. Whereas studies in an American context, for example, point to increasing marginalisation of cultural journalism in the press (NAJP 1999, 2004) and in television (NAJP 2000), cultural journalism in the Nordic countries seems to be thriving and to have expanded (Larsen 2008; Kristensen 2010; Kristensen and From 2011), though competition seems to have increased between an 
aesthetic (and intellectual) and a media- professional paradigm (Hellman and Jaakkola 2012). Furthermore, studies show that in specific national settings elite newspapers may be characterised by an intellectualising discourse on various popular cultural topics, for example movies in an American context (Baumann 2001) and popular music in a European context (Larsen and Jensen 2010). Van Venrooij and Schmutz's (2010) comparative study of popular music coverage, for example, shows that the cultural review in Germany continues to have strong ties to a conception of culture and critique "that values idealism and intellectualism and therefore high art discourse appears to be a potent means to achieving legitimacy" (van Venrooij and Schmutzs 2010, 413).

These national similarities and differences emphasise the significance both of comparative approaches to the study of cultural journalism and of national studies of domestic specificities. In this special issue we try to include both, since some articles apply a geographical crosscut to the study of cultural journalism and critique, while others address cultural journalism and critique in particular national settings. Several articles by scholars from the Nordic countries, for example, imply that media systems within the democratic corporative model (Hallin and Mancini 2004) seem to be continuing their long tradition of providing an arena for critique, cultural and societal debate, as well as cultural news (Hemer and Forsare 2010) - perhaps to a greater extent than their British and American counter- parts, which adhere to a more liberal media model.

\section{Digital Cultural Journalism and Online Critique}

A dominating perspective in contemporary studies of journalism practice, and in this special issue as well, is digitalisation, and how "digitalisation is changing journalistic practices, cultures and institutions" (Steensen and Ahva 2015, 1). Wahl-Jorgensen and Hanitzsch (2009) distinguish four phases in the history of journalism research: the normative, the empirical, the sociological, and the global-comparative phase. The last phase is primarily associated with the blurring of boundaries between, for example, professionals and amateurs, the public and the private, the local and the global, etc.: phenomena that are seen, precisely, as outcomes of digitalisation and globalisation. As indicated, the blurring of boundaries in cultural and lifestyle journalism concerns the cultural outlook and content exemplified by the increasing orientation towards globalised cultural products (Janssen, Kuipers, and Verboord 2008) and a service discourse (Eide and Knight 1999; Kristensen and From 2011, 2012). Moreover, social media have dissolved the boundaries between professional cultural critics and amateur voices, who currently speak up as both public and private personas (Kammer 2015; Kristensen and From 2015a; Verboord 2014), which challenges our understanding of the relation between producer and consumer (Bruns 2008; Örnebring 2008) but also between the critical genres of cultural journalism such as previews and reviews, reviews and criticism (Gillespie 2012). Thus as several of the articles in this special issue show, digital technologies, participatory practices, and the decentring of journalism have challenged both the aesthetic tradition and the more recent media-professional logic of cultural journalism. Ordinary citizens or "amateurs" are engaging in thriving cultural debates and reviewing on multiple media platforms by providing and exchanging experience-based cultural evaluations. This diversity of voices in cultural debate, especially on digital media platforms, necessitates a more heuristic definition of critique as concept, as well as of more specific critical genres (Gillespie 2012, 61). In other words, digitalisation is an almost inescapable perspective in the current phase of journalism studies, and in research on cultural journalism and cultural critique more specifically. Therefore, many of the articles in this special issue address digitalisation as one pivotal parameter, often intermeshed with globalisation and/or commercialisation, but none- theless deserving attention in and of itself because of its fundamental impact on contemporary cultural journalism and critical practices.

\section{New Inputs to Emerging Research on Cultural Journalism and Critique}

The articles in this special issue contain theoretically and empirically focused contributions to the contemporary study of cultural journalism and mediated cultural critique. One group of articles provides new knowledge on cultural journalism as a professional practice, including the specificities that distinguish this branch of journalism from other types of journalism. That is, specificities that are the constant centre- 
point for professional challenge and self-reflection, but which also emphasise the importance and contribution of this specialised type of journalism to contemporary media and news culture. Another group of articles attends to the changing nature of cultural critique in a digital media landscape by scrutinising the co-existing variety of critical voices. These articles to some extent counter-balance the normative-critical approach often taken to the rise or increasing dominance of non-professional discourses.

In their article "The Political in Cultural Journalism: Fragmented Interpretive Communities in the Digital Age," Riegert, Rooswall, and Widholm demonstrate how Swedish cultural journalists across different media platforms can be seen as different interpretative sub-communities. In this manner, the authors place Swedish cultural journalism research on the international agenda, since the limited Swedish research that exists has not been published in English (e.g., Hemer and Forsare 2010; Lundqvist 2012). Furthermore, they apply approaches to the study of cultural journalism that have been relatively absent in previous international research, by focusing on the critical-political potential and nature of cultural journalism and by investigating cultural journalism across various media platforms. Based on qualitative interviews with cultural editors from various Swedish media institutions-newspapers, television, and radio-their article thus provides the first detailed view of the self-understanding, ideology (Deuze 2005), or interpretive community (Zelizer 1993) of prominent cultural agenda-setters or intermediaries in Swedish media culture and society. Riegert, Rooswall, and Widholm argue that even within this specialised field of journalism, various interpretive sub-communities exist across various media platforms. Their argument is that this points to the importance of scrutinising cultural journalism not only on its own terms, but also within its specific media institutional contexts, in order to fully understand its logic, potentials, and current challenges.

In contrast to Sweden, cultural journalism has been studied more intensively in a Norwegian context. In the early 1990s, Bech-Karlsen (1991) lamented the increasingly broad cultural palette competing for the news media's attention, along with the decline of art and cultural critique at a time of popular cultural excess and rapidly expanding cultural industries. At the same time, Eide (1992; Eide and Knight 1999) proposed "service journalism" as a term for an emerging kind of journalism providing guidance on matters of cultural consumption and life-choices in an increasingly complex society and everyday life. Service journalism later became a seminal term in research on journalism on culture, lifestyle, and consumption (e.g., Hanusch 2012; Kristensen and From 2012). Also in more recent years, Norwegian scholars have conducted important research on the changing cultural public sphere (e.g., Knapskog and Larsen 2008). In their contribution to this special issue, "Doubly Dominated: Cultural Journalists in the Fields of Journalism and Culture," Hovden and Knapskog continue this line of work by providing a Bourdieusian-inspired field-theoretical framework and extensive empirical evidence for the constant struggles for legitimacy of cultural journalists-both within the journalistic field and editorial hierarchy and within the cultural field, among other things due to their shortage of symbolic capital in both fields.

Finnish scholars too have in recent years contributed considerably to placing the study of cultural journalism on the international research agenda with a series of journal articles focusing especially on the competing and sometimes conflicting paradigms or self- understandings of cultural journalists alluded to above - the aesthetic paradigm, and the increasingly news-oriented paradigm. These rival models have led to a discourse of crisis or decline with regard to this specialised type of journalism also (e.g., Hellman and Jaakola 2012; Jaakkola 2014). In their contribution to this special issue, "Liquid Modern Journalism with a Difference: The Changing Professional Ethos of Cultural Journalism," Jaakkola, Hellman, Koljonen, and Väliverronen continue this line of work by taking their point of departure in the concept of "liquid modernity" (Bauman 2000), later altered to "liquid journalism" (Deuze 2008), in order to analyse how the changes in professional journalism more generally from high modernity to liquid modernity have played out differently in cultural journalism, precisely because of the fundamentally different nature of this specialised type of journalism.

In recent years, comparative studies have increasingly come to dominate interna- tional media and journalism research (e.g., Benson et al. 2012; Esser 2013; Hallin and Mancini 2004; Kuhn and Nielsen 2014). As already alluded to, these studies have primarily focused on news journalism, political journalism, 
or on cross-national differences and similarities in online and offline journalism. Exceptions are, however, Larsen and Jensen's (2010) study of the coverage of music in European newspapers in the second half of the twentieth century, and even more importantly, the work of Janssen, Kuipers, and Verboord (2008; Janssen, Verboord, and Kuipers 2011), who have compared the arts and cultural coverage in American and European newspapers and thus document the internationalisation (or "Americanisation") of European cultural journalism in light of the diffusion and increasing dominance of American cultural products and industries. Also in this special issue Janssen and Verboord contribute a comparative perspective, based on a large dataset on cultural journalism in American, Dutch, French, and German newspapers from the middle of the twentieth century to the mid-2000s, with a focus on, among other things, the interplay between content and advertising. In their article "Arts Journalism and its Packaging in France, Germany, the Netherlands, and the United States, 1955-2005," they point to an increasing accommodation to reader interests (more so in American newspapers than in European) and imply that despite the specialised nature of cultural journalism, some of the media systemic differences and similarities, pointed to by Hallin and Mancini's (2004) influential models, also play out in the context of cultural journalism.

Cultural critique has, as indicated, been altered by the newer digital technologies and the changing business models of public media and niche outlets. In continuation of their previous work on cultural journalism, especially in the Danish printed press (From 2010; Kristensen and From 2011, 2015b; Kristensen 2010), Kristensen and From in the article "From Ivory Tower to Cross-media Personas: The Heterogeneous Cultural Critic in the Media" provide a theoretical typology of four rival, yet converging ideal types of cultural critics in contemporary media culture. Under the term "the heterogeneous cultural critic," they propose (1) the intellectual cultural critic, (2) the professional cultural journalist, (3) the mediamade arbiter of taste, and (4) the everyday amateur expert as important voices currently framing cultural goods in different ways and based on various forms of cultural expertise, authority, or capital. This mainly theoretical contribution may hopefully inspire future empirical research into the complex digital media environment, its mixed voices, and its potentiality for new conceptualisations of the cultural public sphere.

In the article "Post-industrial Cultural Criticism: The Everyday Amateur Expert and the Online Cultural Public Sphere," Aske Kammer's analysis of websites with reviews of arts and culture based on "amateur" contributions provides an important study of the engagement of audiences in contemporary cultural critique, including the potentials for and actualisations of public discourse on the cultural field. Even though social and digital media are growing research fields, previous research has only to a limited extent focused on the interrelations between the cultural public sphere and non-organisational agents reviewing, commenting, and discussing diverse cultural topics. Kammer's contribution builds on his solid research in digital media and news on the Web (e.g., Kammer 2013), and in this article he analyses how post-industrial cultural journalism, on the one hand, constitutes "a vibrant, extensive and diverse field for public discussion" (Kammer 2015); on the other hand, his analysis shows that the contributing agents often have an academic background in the humanities, which may imply that the aesthetic paradigm is resurfacing and reinventing itself in a digital media culture, and that the amateur critic does not necessarily represent a de-professionalisation, as argued formerly by professional journal- ists and scholars (e.g., Hermida 2011; Örnebring 2008), but rather a re-professionalisation of cultural critique.

Andrew McWhirter, in the article "Film Criticism in the Twenty-first Century: Six Schools," also contributes an analysis of cultural criticism from the perspective of the producing agents. Based on a thorough reading of existing British and American outlets for film criticism, combined with 30 interviews with practising film critics, he provides a model of six schools of film criticism: (1) the academic school, (2) the sophisticated school, (3) the populist school, (4) the trade school, (5) the consumer school, and (6) the school of fandom. The model represents six different ways of addressing an audience by showing how film critics establish different types of contracts with their readers by engaging with different purposes of film criticism, ranging from critic reflection to engaged fandom.

Finally, Anne-Sophie Béliard's article "When Cultural Criticism Blurs Cultural Hier- archies: The Case of Series Journalism in France" explores how television series have emerged and been established as a new topic in French cultural criticism. Based on interviews with magazine journalists writing on television 
series, as well as on a qualitative reading of the two leading magazines in France dedicated to television series, Génération Séries and Génériques, this contribution exemplifies how cultural criticism of a popular cultural phenomenon (such as a television series) reflects the more general tendency of increasingly blurred boundaries between lowbrow and highbrow culture-or, as Herbert J. Gans puts it, that "the differences between high culture and popular culture have been exaggerated and the similarities, underestimated" (Gans 1999, xiv). At the same time, Béliard argues that these significant magazines are reinventing a cultural hierarchy, and (in line with Janssen, Verboord and Kuipers (2011)) that globalisation and Americanisation are important explanatory frameworks for understanding contemporary French criticism, in the sense that not all types or genres of television series are equally valued. Thus, the analysis exemplifies how cultural criticism may contribute to the establishment of new cultural hierarchies, as well as the dissolving of cultural structures and ideologies.

\section{Concluding Remarks}

Current and interconnected processes of commercialisation, professionalisation, digitalisation, and globalisation have widened and revitalised the role of cultural journalism in society. These same processes have also blurred the boundaries of what may be labelled "cultural journalism," and they have changed the role of the "cultural journalist." Cultural journalism is more than the coverage of art, ballet, and literatureit also includes economic analyses of the cultural industries, debates on the social impact of contemporary media culture, as well as lifestyle perspectives and guidance on the "good life." Cultural topics — such as fashion, food, film, and television—are complex global phenomena, addressed and debated by journalists, cultural producers, experts, and pundits interchangeably as cultural and aesthetic phenomena, as conveyers or (co-)producers of consumption, lifestyles, and identities, and as omnipresent business ventures. This variety not only emphasises the challenging task of demarcating the field of cultural journalism. It also emphasises the fact that the media today allocate the role of cultural journalist, critic, or arbiter of taste to a miscellany of experts, media professionals, and celebrities from the cultural scene. Furthermore, digital technologies and participatory practices have challenged the profes- sional logics of contemporary cultural journalism and criticism by allowing ordinary citizens or "amateurs" to engage in experience-based cultural debate and evaluation on multiple media platforms. This special issue of Journalism Practice wishes to address these transformations and their implications for the professional practice of cultural journalism and cultural critique.

\section{Disclosure statement}

No potential conflict of interest was reported by the authors.

\section{References}

Appadurai, Arjun. 1996. Modernity at Large: Cultural Dimensions of Globalization. Minneapolis: University of Minnesota Press.

Bauman, Zygmunt. 2000. Liquid Modernity. Cambridge: Polity Press.

Baumann, Shyon. 2001. "Intellectualization and Art World Development: Film in the United States." American Sociological Review 66 (3): 404-426. doi:10.2307/3088886.

Baumann, Shyon. 2007. "A General Theory of Artistic Legitimation. How Art Worlds Are Like Social Movements.” Poetics 35 (1): 47-65. doi:10.1016/j.poetic.2006.06.001.

Bech-Karlsen, Jo. 1991. Kulturjournalistikk. Avkobling eller tilkobling? [Cultural Journalism. Decoupling or Coupling?] Oslo: Universitetsforlaget.

Béliard, Anne-Sophie. 2015. "When Cultural Criticism Blurs Cultural Hierarchies. The Case of Series Journalism in France.” Journalism Practice doi:10.1080/17512786.2015.1051373.

Benson Rodney, Mark Blach-Ørsten, Matthew Powers, Ida Willig, and Sandra Vera Zambrano. 2012.

"Media Systems Online and Off: Comparing the Form of News in the United States, Denmark and

France.” Journal of Communication 62 (1): 21-38. doi:10.1111/j.1460-2466.2011.01625.x.

Berkowitz, Dan, and Lyombe Eko. 2007. "Blasphemy as Sacred Rite/right: 'The Mohammed Cartoons 
Affair' and Maintenance of Journalistic Ideology.” Journalism Studies 8 (5): 779-797.

Bordwell, David. 1991. Making Meaning. Cambridge: Harvard University Press.

Bourdieu, Pierre. 1993. The Field of Cultural Production. New York: Columbia University Press.

Bruns, Axel. 2008. Blogs, Wikipedia, Second Life, and Beyond: From Production to Produsage. NewYork: Peter Lang.

Curran, James. 2011. Media and Democracy. London: Routledge. Deuze, Mark. 2005. "What is Journalism? Professional Identity and Ideology of Journalism Reconsidered.” Journalism 6 (4): 442-464.

Deuze, Mark. 2007. Media Work. Cambridge: Polity Press.

Deuze, Mark. 2008. "The Changing Context of News Work: Liquid Journalism and Monitorial Citizenship.” International Journal of Communication 2 : 848-865.

Dubied, Annik, and Thomas Hanitzsch. 2014. "Introduction: Studying Celebrity News." Journalism: Theory, Practice and Criticism 15 (2): 137-143.

Eide, Martin. 1992. Den Fjerde Servicemakt - noter til forståelse av norsk veilednings- og kampanjejournalistikk [The Fourth Service Estate - Notes to the Comprehension of Norwegian Guidance- and Campaign Journalism]. Bergen: Institut for Massekommunikasjon.

Eide, Martin, and Graham Knight. 1999. "Public/private Service: Service Journalism and the Problems of Everyday Life.” European Journal of Communication 14 (4): 525-547. doi:10.1177/0267323199014004004.

Esser, Frank. 2013. "The Emerging Paradigm of Comparative Communication Enquiry: Advancing Crossnational Research in Times of Globalization." International Journal of Communication 7: 113-128.

From, Unni. 2010. “The Reading of Cultural Journal and Lifestyle Journalism.” Northern Lights 8 (1): 157175.

Giddens, Anthony. 1992. The Transformation of Intimacy. Stanford, CA: Stanford University Press.

Gans, Herbert J. 1999. Popular Culture and High Culture: An Analysis and Evaluation of Taste. New York: Basic Books.

Gillespie, Ryan. 2012. "The Art of Criticism in the Age of Interactive Technology: Critics, Participatory Culture, and the Avant-garde." International Journal of Communication 6: 56-75.

Gripsrud, Jostein. 2000. “Tabloidization, Popular Journalism, and Democracy.” In Tabloid Tales: Global Debates over Media Standards, edited by Colin Sparks and John Tulloch, 285-300. Lanham, MD: Rowman and Littlefield.

Gripsrud, Jostein. 2009. "The Cultural Dimension of Democracy.” In Media, Democracy and European Culture, edited by Ib Bondebjerg and Peter Madsen., 197-214. Bristol: Intellect Books.

Hallin, Daniel C., and Paolo Mancini. 2004. Comparing Media Systems. Cambridge: Cambridge University Press.

Hanusch, Folker. 2012. "Broadening the Focus. The Case for Lifestyle Journalism as a Field of Scholarly Inquiry.” Journalism Practice 6 (1): 2-1.

Hanusch, Folker. 2013. Lifestyle Journalism. Oxon: Routledge.

Harries, Gemma, and Karin Wahl-Jorgensen. 2007. “The Culture of Arts Journalists.” Journalism 8 (6):619-639.

Hellman, Heikki, and Maarit Jaakkola. 2012. "From Aesthetes to Reporters: The Paradigm Shift in Finland.” Journalism 13 (6): 783-801. doi:10.1177/1464884911431382.

Hemer, Oscar, and Malena Forsare, eds. 2010. Kulturjournalistikens gränser [The Boundaries of Cultural Journalism]. Umeå: H:ström Text \& Kultur. Herman, Edward S., and Robert W. McChesney. 1997. The Global Media. London: Cassell.

Hermida, Alfred. 2011. "Mechanisms of Participation: How Audience Options Shape the Conversation." In Participatory Journalism: Guarding Open Gates at Online Newspapers, edited by Jane B. Singer, Alfred Hermida, David Domingo, Ari Heinonen, Steve Paulussen, Thorsten Quandt,Zvi Reich, and Marina Vujnovic. Malden: Wiley-Blackwell.

Hjarvard, Stig. 2010. "The Views of the News." Northern Lights 8: 25-48.

Hjarvard, Stig. 2013. The Mediatization of Culture and Society. London: Routledge. 
Holopirek, Jody Ann. 2007. Online Journalism: The Transformation of the Film Review. Ann Arbor: University of Kansas.

Hovden, Jan-Fredrik, and Karl Atle Knapskog. 2008. "Kulturjournalistikken i det norske journalistiske feltet [Cultural Journalism in the Norwegian Journalistic Field].” In Kulturjournalistikk [Cultural Journalism. The Press and the Cultural Public Sphere], edited by Karl Atle Knapskog and Leif Ove Larsen, 51-70. Oslo: Scandinavian Academic Press.

Hovden Jan-Fredrik, and Karl Atle Knapskog. 2015. "Double Dominated. Cultural Journalists in the Fields of Journalism and Culture.” Journalism Practice doi:10.1080/17512786.2015. 1052214.

Jacobs, Ronald N., and Eleanor Townsley. 2011. The Space of Opinion: Media Intellectuals and the Public Sphere. New York, NY: Oxford University Press.

Jaakkola, Maarit. 2014. "Witnesses of a Cultural Crisis: Representations of Media-related Metaprocesses as Professional Metacriticism of Arts and Cultural Journalism.” International Journal of Cultural Studies. Online first February 2, 2014.

Janssen, Susanne. 1999. “Art Journalism and Cultural Change.” Poetics 26 (5-6): 329-348.

Janssen, Susanne, Gisele Kuipers, and Marc Verboord. 2008. "Cultural Globalization and Journalism: The International Orientering of Arts and Culture Coverage in Dutch, French, German, and U.S. Newspapers, 1955 to 2005.” American Sociological Review 73: 719-740.

Janssen, Susanne, Marc Verboord, and Gisele Kuipers. 2011. "Comparing Cultural Classification. High and Popular Arts in European and US-elite Newspapers.” Kölner Zeitschrift für Soziologie und Sozialpsychologie 51: 139-168.

Jenkins, Henry. 2006. Convergence Culture: Where Old and New Media Collide. New York: New York University Press.

Kammer, Aske. 2013. "News on the Web: Instantaneity, Multimodality, Interactivity, and Hypertextuality." $\mathrm{PhD}$ diss., University of Copenhagen.

Kammer, Aske. 2015. "Post-industrial Cultural Criticism: The Everyday Amateur Critic and the Online Cultural Public Sphere.” Journalism Practice doi:10.1080/17512786.2015.1051371.

Knapskog, Karl Atle, and Leif Ove Larsen, eds. 2008. Kulturjournalistikk [Cultural Journalism. The Press and the Cultural Public Sphere]. Oslo: Scandinavian Academic Press.

Kristensen, Nete Nørgaard. 2010. "The Historical Transformation of Cultural Journalism.” Northern Lights 8: 69-92.

Kristensen, Nete Nørgaard. 2015. "Kulturjournalistikkens dagsordener og dagsordensættere på tværs af platform. Mere af det samme eller øget manfoldighed?” In Mediernes dagsordensættende magt, edited by Mark Blach-Ørsten and Ida Willig. Frederiksberg: Samfundslitteratur.

Kristensen, Nete Nørgaard, and Unni From. 2011. “Kulturjournalistik. [Cultural Journalism]” Journalistik om Kultur [Journalism on Culture]. Frederiksberg: Samfundslitteratur.

Kristensen, Nete Nørgaard, and Unni From. 2012. "Lifestyle Journalism: Blurring Boundaries.” Journalism Practice 6 (1): 26-41.

Kristensen, Nete Nørgaard, and Unni From. 2013. "Blockbusters as Vehicles for Cultural Debate in Cultural Journalism." Academic Quarter 7, special issue on Bestseller and Blockbuster Culture.

Kristensen, Nete Nørgaard, and Unni From. 2015a. "From Ivory Tower to Cross-media Personas: The Heterogeneous Cultural Critic in the Media." Journalism Practice doi:10.1080/17512786.2015.1051370.

Kristensen, Nete Nørgaard, and Unni From. 2015b. "Publicity, News Content, and Cultural Debate: A Case Study of the Changing Coverage of Blockbuster Movies in Cultural Journalism.”

Communication, Culture \& Critique. doi:10.1111/cccr.12094.

Kuhn, Raymond, and Rasmus Kleis Nielsen, eds. 2014. Political Journalism in Transition: Western Europe in a Comparative Perspective. London: I.B. Tauris.

Larsen, Leif Ove. 2008. "Forskyvninger: Kulturdekningen i norske dagsaviser 1964-2005 [Shiftings: The Cultural Coverage in Norwegian Newspapers 1964-2005]”. In Kulturjour- nalistikk. Pressen og den kulturelle offentlighed [Cultural Journalism. The Press and the Cultural Public Sphere], edited by Karl 
Atle Knapskog and Leif Ove Larsen. Oslo: Scandinavian Academic Press.

Larsen, Peter and Klaus Bruhn Jensen. 2010. "The Sounds of Change: Representations of Music in European Newspapers 1960-2000”. In Media, Markets \& Public Spheres: European Media at the Crossroads, edited by I. B. Bondebjerg and Peter Madsen, 249-265. Chicago: Intellect.

Lavik, Erland. 2008. "Filmkritikk i den digitale tidsalderen.” In Kulturjournalistikk, edited by Karl Atle Knapskog and Leif Ove Larsen. Oslo: Scandinavian Academic Press.

Lund, Cecilie W. 2005. Kritikk og kommers. Kulturdekningen i skandinavisk dagspresse [Critique and Business. The Cultural Coverage in the Scandinavian Press]. Oslo: Universitetsforlaget.

Lundqvist, Åke. 2012. Kultursidan: kulturjournalistiken i Dagens Nyheter 1864-2012 [The Cultural Page: Cultural Journalism in Dagens Nyheter 1864-2012]. Stockholm: Albert Bonniers Forlag.

Marker, Lasse. 2014. 6 grunde til, at der ikke sker en skid i dansk kulturliv [6 Reasons Why Nothing Worth a Damn Is Happening in Danish Cultural Life]. København: DOXA.

Marshall, David P. 2006. "Intimately Intertwined in the Most Public Way: Celebrity and Journalism." In The Celebrity Culture Reader, edited by P. David Marshall. 315-324. New York, NY: Routledge.

McGuigan, Jim. 2005. “The Cultural Public Sphere.” European Journal of Cultural Studies 8 (4):427-443. NAJP. 1999. Reporting the Arts I. Seattle, WA: Columbia University/National Arts Journalism Program.

NAJP. 2000. Television and the Arts. Seattle, WA: Columbia University/National Arts Journalism

Program.

NAJP. 2004. Reporting the Arts II. Seattle, WA: Columbia University/National Arts Journalism Program. Örnebring, Henrik. 2008. “The Consumer as Producer—of What?” Journalism Studies 9 (5):771-785.

Picard, Robert. 2010. "The Future of the News Industry.” In Media and Society, edited by James Curran.

New York, NY: Bloomsbury Academics.

Reinemann, Carsten, James Stanyer, Sebastian Scherr and Guido Legnante. 2011. "Hard and Soft News: A Review of Concepts, Operationalizations and Key Findings.” Journalism 13 (2):221-239.

Riegert, Kristina, Anna Roosvall, and Andreas Widholm. 2015. "Kulturjournalistik [Cultural Journalism]." In Handbok i journalistikforskning [Handbook in Journalism Research], edited by Michael Karlsson and Jesper Strömbäck. Lund: Studentlitteratur.

Said, Edward W. 1984. The World, the Text, and the Critic. London: faber and faber.

Steensen, Steen, and Laura Ahva. 2015. "Theories of Journalism in a Digital Age." Journalism Practice 9 (1): $1-18$.

Strahan, Lucinda. 2011. "Sources of Arts Journalism. Who"s Writing the Arts Pages?” In Journalists, Sources, and Credibility, edited by Bob Franklin and Matt Carlson, 127-138. London: Routledge.

Turner, Barry, and Richard Orange, eds. 2013. Specialist Journalism. New York: Routledge.

Venrooij, Alex van, and Vaughn Schmutzs. 2010. "The Evaluation of Popular Music in the United States, Germany and the Netherlands: A Comparison of the Use of High Art and Popular Aesthetic Criteria." Cultural Sociology 4 (3): 395-421.

Verboord, Marc. 2011. "Cultural Products Go Online: Comparing the Internet and Print Media on Distributions of Gender, Genre and Commercial Success.” Communications 36: 441-462.

Verboord, Marc. 2014. "The Impact of Peer-produced Criticism on Cultural Evaluation: A Multilevel Analysis of Discourse Employment in Online and Offline Film Reviews." New Media \& Society 16 (6): 921-940.

Vik, Kari Aakerli. 2008. "Fra "professorstyrt" folkeopplysning til "journaliststyrt" opplevelsesfjernsyn." In Fjernsyn i digitale omgivelser, edited by Roel Puijk, 125-164. ij-forlaget

Wahl-Jorgensen, Karin and Thomas Hanitzsch 2009. "Introduction: On Why and How We Should Do Journalism Studies.” In Handbook of Journalism Studies, edited by Karin Wahl-Jorgensen and Thomas Hanitzsch, 3-16. Oxon: Routledge.

Zelizer, Barbie. 1993. "Journalists as Interpretive Communities." Critical Studies in Mass Communication 10 (3): 219-237. 
Nete Nørgaard Kristensen (author to whom correspondence should be addressed), Department of Media, Cognition and Communication, University of Copen- hagen, Denmark. E-mail: netenk@hum.ku.dk

Unni From, Department of Communication and Aesthetics, Aarhus University, Denmark. E-mail: imvuf@dac.au.dk 